\title{
PENGARUH METODE DAN SUHU BLANCHING TERHADAP PERSENYAWAAN SERAT BATANG PISANG SEBAGAI BAHAN BAKU PEMBUATAN ARES
}

\author{
[The Effect of Methods and Temperature of Blanching Treatment on Fiber Compounds of Banana Stem as \\ Raw Material of Ares]
}

\author{
Arin Tria Agustin*, Mohammad Abbas Zaini, dan Dody Handito \\ Program Studi Ilmu dan Teknologi Pangan, Fakultas Teknologi Pangan dan Agroindustri, \\ Universitas Mataram \\ *Email: arintriaa@gmail.com
}

Diterima 05 September 2019 / Disetujui 7 Juli 2020

\begin{abstract}
This study aims to determine the combination of methods and temperature of blanching treatment on crude fiber content, total dietary fiber, insoluble dietary fiber content and soluble dietary fiber content of banana steam as raw material of ares. The experimental design used in this study was Completely Randomized Block Design (CRBD) factorial with six treatments and three repetitions to obtain 18 samples. The combination of treatment consisted of M1T1 (steaming $75^{\circ} \mathrm{C}$ ), M1T2 (steaming $85^{\circ} \mathrm{C}$ ), M2T1 (boiling $75^{\circ} \mathrm{C}$ ), M2T2 (boiling $85^{\circ} \mathrm{C}$ ), M3T1 (boiling with Na2S2O5 0,1\% solution 75 $\mathrm{C}$ ), M3T2 (boiling with Na2S2O5 $0,1 \%$ solution $85^{\circ} \mathrm{C}$ ). The result of this study were analyzed using ANOVA (Analysis of Variance) diversity analysis at 5\% level using Co-Stat Software. The result that had significant differences were continued to analyzed using Honestly Significant Different Test (BNJ) at 5\% real level. The result showed that the combination of methods and temperature of blanching treatment did have a significant effect oncrude fiber content, insoluble dietary fiber content, soluble dietary fiber content dan total dietary fiber content. The best result of banana stem based on nutritional quality of fiber was steaming $75^{\circ} \mathrm{C}$ treatment with crude fiber content $0.5413 \%$, total dietary fiber content $22.059 \%$, insoluble dietary fiber content $19.978 \%$ and soluble dietary fiber content $2.081 \%$. The best result of Ares based on nutritional quality of fiber was steaming $75^{\circ} \mathrm{C}$ treatment with crude fiber content 4,321\%, total dietary fiber content 46,057\%, insoluble dietary fiber content $42,112 \%$ and soluble dietary fiber content $3,945 \%$.
\end{abstract}

Keywords: ares, banana stem, blanching, crude fiber, dietary fiber.

\section{ABSTRAK}

Penelitian ini bertujuan untuk mengetahui pengaruh kombinasi metode dan suhu blanching terhadap kadar serat kasar, kadar serat pangan total, kadar serat pangan tidak larut dan kadar serat pangan larut batang pisang sebagai bahan baku pembuatan Ares. Rancangan percobaan yang digunakan adalah Rancangan Acak Kelompok (RAK) pola faktorial dengan enam kombinasi perlakuan dan tiga kali pengulangan sehingga diperoleh 18 sampel. Kombinasi perlakuan terdiri dari M1T1 (pengukusan $75^{\circ} \mathrm{C}$ ), $\mathrm{M} 1 \mathrm{~T} 2$ (pengukusan $85^{\circ} \mathrm{C}$ ), M2T1 (perebusan $75^{\circ} \mathrm{C}$ ), M2T2 (perebusan $85^{\circ} \mathrm{C}$ ), M3T1 (perebusan dengan larutan Na2S2O5 $0,1 \%$ $75^{\circ} \mathrm{C}$ ), M3T2 (perebusan dengan larutan Na2S2O5 $0,1 \% 85^{\circ} \mathrm{C}$ ). Data hasil pengamatan diuji dengan analisis keragaman pada taraf nyata $5 \%$ menggunakan software Co-Stat. Apabila terdapat perbedaan nyata, maka dilakukan uji lanjut Beda Nyata Jujur (BNJ) pada taraf 5\%. Hasil terbaik batang pisang berdasarkan mutu nutrisi serat yaitu perlakuan pengukusan $75^{\circ} \mathrm{C}$ dengan kadar serat kasar $0,5413 \%$, kadar serat pangan tidak larut $19,978 \%$, kadar serat pangan larut 2,081\% dan kadar serat pangan total $22,059 \%$. Hasil terbaik pada ares berdasarkan mutu nutrisi serat adalah perlakuan pengukusan pada suhu $75^{\circ} \mathrm{C}$ dengan kadar serat kasar $4,321 \%$, serat pangan total $46,057 \%$, serat pangan tidak larut $42,112 \%$ dan serat pangan larut $3,945 \%$.

Kata kunci: Ares, batang pisang, blanching, serat kasar, serat pangan.

\section{PENDAHULUAN}

Pisang (Musa paradisiaca) merupakan salah satu buah unggulan Indonesia, dikenal sebagai tanaman herba yang berasal dari Asia Tenggara termasuk Indonesia. Secara umum pisang memiliki kandungan gizi yang baik, karena kaya akan karbohidrat, mineral dan vitamin. Tanaman pisang mengandung berbagai senyawa seperti air, gula pereduksi, sukrosa, pati, protein kasar, pektin, lemak kasar, serat kasar dan abu (Ahda dan Berry, 2008). Kandungan senyawa dalam $100 \mathrm{~g}$ buah pisang yaitu air sebanyak $73,60 \%$, protein $2,15 \%$, lemak $1,34 \%$, gula pereduksi $7,62 \%$, pati $11,48 \%$, serat kasar $1,52 \%$, abu $1,03 \%$, vitamin C $36 \%$, kalsium $31 \%$, besi $26 \%$ dan 
fosfor 63\% (Dewati, 2008). Menurut Anonim (2006), salah satu kandungan terpenting pada batang pisang adalah serat. Serat berfungsi untuk mencegah sembelit dan memperlancar buang air besar. Selain itu, serat juga dapat menyembuhkan kanker usus besar, luka serta benjolan di dalam usus besar, serta dapat menurunkan kadar kolesterol dalam darah.

Berdasarkan data FAO 2013, Indonesia menempati urutan keenam dengan total produksi pisang 6.189.052 ton. India menempati urutan pertama dengan total produksi 26.509.096 ton, kemudian Cina dengan 10.550.000 ton, Filipina dengan 9.225.998 ton, Ekuador dengan 7.012.244, dan Brasil dengan 6.902.184 ton (Indian Horticulture Database dalam Anonim, 2017). Di Indonesia sendiri, pisang merupakan salah satu komoditas buah unggulan. Menurut Badan Pusat Statistik (2015), produksi pisang pada tahun 2014 mencapai 6.862 .567 ton, kemudian mengalami peningkatan pada tahun 2015 yaitu sebanyak 7.299.275 ton dengan persentase pertumbuhan sebesar $6,36 \%$. Pisang menjadi komoditi dengan produksi terbanyak pada tahun 2015, mengalahkan produksi buah mangga dan buah jeruk siam.

Produksi dari tanaman pisang juga melimpah di wilayah Nusa Tenggara Barat. Berdasarkan Badan Pusat Statistik Provinsi NTB (2017), menunjukan bahwa pisang merupakan komoditi dengan produksi tertinggi ketiga setelah mangga dan nanas. Secara total, pada tahun 2016 produksi pisang di NTB mencapai 75,5 ribu ton yang tersebar di seluruh kabupaten/kota, dengan produksi tertinggi pada kabupaten Lombok Barat yaitu menghasilkan 17,95 ribu ton pisang. Tingginya produksi pisang di provinsi NTB juga meningkatkan limbah tanaman pisang. Hal tersebut dikarenakan bagian dari tanaman pisang yang paling banyak dimanfaatkan oleh masyarakat adalah buah dan daunnya. Sedangkan bagian lain seperti batang pisang biasanya hanya dijadikan sebagai pakan ternak. Namun, di provinsi NTB batang pisang dapat diubah menjadi olahan lezat dan memiliki kandungan nutrisi yang baik bagi kesehatan manusia, yaitu ares.

Ares merupakan masakan tradisional khas suku Sasak di daerah Lombok, Nusa Tenggara Barat. Ares pada dasarnya adalah suatu bentuk sumber daya lokal yang belum dikembangkan secara optimal. Hal ini dikarenakan pengolahannya hanya untuk acara-acara adat dan belum banyak dikonsumsi sebagai makanan sehari-hari. Ares memiliki peluang untuk mengangkat ciri khas suku Sasak dalam bidang kuliner (Soebyanto dkk., 2018). Ares merupakan olahan yang dibuat dari batang pisang yang masih muda. Cara pembuatan Ares adalah dengan mengupas batang pisang hingga menyisakan sedikit bagian dalamnya. Pohon pisang yang dipakai adalah batang yang belum memiliki bunga. Bagian tersebut diiris tipis lalu diberi garam, diremas-remas dan dicuci hingga bersih sebelum akhirnya diolah. Bumbu yang digunakan mirip dengan bumbu kare yaitu ketumbar, jintan, lengkuas, bawang putih, bawang merah, jahe, kemiri dan kunyit. Bumbu tersebut dimasak dengan batang pisang yang sudah dipotong-potong kemudian ditambahkan garam dan gula (Yustitia, 2012).

Kendala dalam pengolahan ares adalah batang pisang yang cepat mengalami reaksi pencokelatan enzimatis setelah dilakukan pemotongan. Pencokelatan enzimatis tidak diinginkan karena pembentukan warna cokelat pada buah atau sayur sering diartikan sebagai bentuk kerusakan dan penurunan mutu. Salah satu cara untuk mencegah terjadinya reaksi enzimatis yaitu dengan menginaktivasi enzim oksidase, misalnya dengan pemanasan (blanching) (Kusnandar, 2010). Selain itu perlakuan pendahuluan lain yang dapat dilakukan adalah dengan menambahkan bahan seperti natrium metabisulfit $\left(\mathrm{Na}_{2} \mathrm{~S}_{2} \mathrm{O}_{5}\right)$ yang dapat menghambat reaksi pencokelatan (Arsa, 2016).

Kusdibyo dan Musaddad (2000), menunjukkan bahwa perlakuan blanching dengan media air pada suhu $80^{\circ}-90^{\circ} \mathrm{C}$ 
Versi Online:

http://www.profood.unram.ac.id/index.php/profood e-ISSN: 2443-3446

selama 10 menit dapat meningkatkan kecerahan warna, kandungan nutrisi dan tekstur wortel. Asgar dan Musaddad (2006) dalam penelitiannya menunjukkan bahwa blanching media air selama 10 menit pada suhu $75^{\circ} \mathrm{C}$ menghasilkan mutu kubis kering terbaik dan pada suhu $85^{\circ} \mathrm{C}$ untuk mutu wortel kering terbaik. Kemudian hasil penelitian Asgar dan Musaddad (2008), menunjukkan bahwa perlakuan blanching terbaik untuk lobak kering yaitu dengan media uap pada suhu $75^{\circ} \mathrm{C}$ selama 10 menit. Penerapan metode dan suhu blanching untuk perlakuan pendahuluan pada batang pisang belum dilakukan, oleh karena itu dilakukan penelitian untuk menentukan kombinasi metode dan suhu blanching terhadap kadar serat kasar, kadar serat pangan total, kadar serat pangan tidak larut dan kadar serat pangan larut dari batang pisang sebagai bahan baku pada pembuatan ares.

\section{BAHAN DAN METODE}

\section{Bahan}

Bahan-bahan yang digunakan dalam penelitian ini adalah batang pisang kepok berumur \pm 3 bulan dari petani di Kelurahan Karang Baru kota Mataram. Bawang merah, bawang putih, jahe, kunyit, lengkuas, kemiri, garam dapur, gula, cabai merah, cabai rawit, minyak goreng, santan dan air yang dibeli dari pasar Kebon Roek. Bahan kimia dengan grade pro-analisis yang digunakan adalah buffer fosfat, enzim alfa-amilase, aquades, enzim protease, amiloglukosidase, aseton, $\mathrm{H}_{2} \mathrm{SO}_{4} 0,255 \mathrm{~N}, \mathrm{NaOH} 0,313 \mathrm{~N}$, etanol 95\%, aquades dan larutan $\mathrm{Na}_{2} \mathrm{~S}_{2} \mathrm{O}_{5} \mathrm{O}, 1 \%$.

Alat-alat yang digunakan dalam penelitian ini adalah panci, panci kukus, baskom, pisau, kompor merk Rinnai dan Hock, blender merk Philips, piring, mangkuk, piring, talenan, penjepit, desikator, Erlenmeyer $100 \mathrm{~mL}$, kertas saring, kapas, timbangan digital merk F-LECO, inkubator merk Memmert, cawan porselin, tanur merk Muffle Furnace, gelas beaker $100 \mathrm{~mL}$, spatula dan oven merk Memmert.
Pro Food (Jurnal IImu dan Teknologi Pangan)

Vol 6 No. 1 Mei 2020

ISSN: 2443-1095

\section{Metode}

Metode yang digunakan dalam penelitian ini adalah metode eksperimental yang dilaksanakan di laboratorium.

\section{Pelaksanaan Penelitian}

\section{Perlakuan Pendahuluan Batang Pisang}

1. Pengirisan

Proses pengirisan dilakukan dengan cara mengiris batang muda pisang sebanyak $100 \%$ (3.000 g) menggunakan pisau menjadi bagian yang lebih kecil dan tipis yaitu sekitar $1 \mathrm{~cm}$.

2. Perendaman dan Pembersihan Getah

Batang pisang yang sudah diiris kemudian ditampung dalam wadah yang berisi air yang sudah ditambahkan dengan garam 2,61\% selama 10 menit. Hal ini bertujuan untuk mempermudah pembersihan dan penghilangan getah. Kemudian dilakukan pembersihan dan pemisahan getah dari batang pisang.

3. Pencucian

Batang pisang yang sudah dibersihkan getahnya selanjutnya dicuci dengan air mengalir agar getah dan rasa garam yang menempel pada batang pisang hilang.

4. Penirisan

Batang pisang yang sudah dicuci bersih kemudian ditiriskan.

5. Blanching

Batang pisang dibagi dalam 6 untuk kebutuhan perlakuan yang berarti masing-masing sebanyak 16,67\% (500 g) kemudian diblanching pada suhu $75^{\circ} \mathrm{C}$ dan suhu $85^{\circ} \mathrm{C}$ selama 10 menit, dengan tiga perlakuan yaitu pengukusan, perebusan dalam air, dan perebusan dalam larutan $\mathrm{Na}_{2} \mathrm{~S}_{2} \mathrm{O}_{5} 0,1 \%$.

6. Perendaman dalam Air

Kemudian dilakukan perendaman di dalam air selama 2 menit. Hal ini bertujuan agar panas dari proses blanching tidak menyebabkan overblanched.

7. Penirisan

Batang pisang yang sudah direndam kemudian kembali ditiriskan. 
Versi Online:

http://www.profood.unram.ac.id/index.php/profood e-ISSN: 2443-3446

\section{Pembuatan Ares}

1. Pencucian

Bumbu-bumbu yang digunakan dalam pembuatan ares, yaitu bawang merah $7,37 \% \mathrm{~b} / \mathrm{b}$, bawang putih $8,75 \% \mathrm{~b} / \mathrm{b}$, jahe $1,52 \% b / b$, kunyit $1,21 \% b / b$, lengkuas $3,98 \% b / b$, kemiri $9,39 \% b / b$, cabai rawit $1,45 \% \mathrm{~b} / \mathrm{b}$, cabai merah $5,42 \%$ b/b (Wahyuni, 2017). Bumbubumbu yang sudah ditimbang selanjutnya dicuci dengan air mengalir.

2. Pengecilan Ukuran

Bahan selanjutnya dipotong menggunakan pisau menjadi bagian yang lebih kecil untuk mempermudah proses penggilingan.

3. Penggilingan

Penggilingan bahan dilakukan dengan menggunakan blender selama 5 menit. Saat proses penggilingan ditambahkan terasi $1,81 \% \quad b / b \quad$ dan untuk mempermudah penghalusan bumbu ditambahkan air 13,33\% b/b.

4. Penumisan

Setelah bumbu halus, dilakukan proses penumisan dengan minyak $18 \% \mathrm{~b} / \mathrm{b}$ pada suhu $100^{\circ} \mathrm{C}$ selama 20 menit.

5. Pemasakan

Proses Pemasakan dilakukan dengan cara mencampur bumbu yang telah ditumis dengan santan $80 \%$ b/b sampai mendidih, kemudian dimasukkan $16,67 \%$ (500 g) batang pisang. Pemasakan dilakukan dengan cara mengaduk secara perlahan agar semua bahan tercampur merata. Proses pemasakan dihentikan setelah \pm 30 menit.

\section{Rancangan Percobaan dan Analisis Data}

Rancangan percobaan yang digunakan adalah Rancangan Acak Kelompok (RAK) pola faktorial dengan enam kombinasi perlakuan dan tiga kali pengulangan sehingga diperoleh 18 sampel. Kombinasi perlakuan terdiri dari M1T1 (pengukusan $75^{\circ} \mathrm{C}$ ), M1T2 (pengukusan $\left.85^{\circ} \mathrm{C}\right), \mathrm{M} 2 \mathrm{~T} 1$
Pro Food (Jurnal Ilmu dan Teknologi Pangan)

Vol 6 No. 1 Mei 2020

ISSN: 2443-1095

(perebusan $75^{\circ} \mathrm{C}$ ), $\mathrm{M} 2 \mathrm{~T} 2$ (perebusan $85^{\circ} \mathrm{C}$ ), M3T1 (perebusan dengan larutan Na2S2O5 $0,1 \% 75^{\circ} \mathrm{C}$ ), M3T2 (perebusan dengan larutan $\mathrm{Na} 2 \mathrm{~S} 2 \mathrm{O} 5 \quad 0,1 \% \quad 85^{\circ} \mathrm{C}$ ). Parameter utama yang diteliti dalam penelitian ini yaitu analisis kadar serat kasar, kadar serat pangan total, kadar serat pangan tidak larut, kadar serat pangan larut dan parameter lainnya yaitu organoleptik (warna, tekstur dan rasa) secara hedonik dan skoring.

\section{Analisis Data}

Data hasil pengamatan diuji dengan analisis keragaman pada taraf nyata $5 \%$ menggunakan software Co-Stat. Apabila terdapat perbedaan nyata, maka dilakukan uji lanjut Beda Nyata Jujur (BNJ) pada taraf $5 \%$.

\section{HASIL DAN PEMBAHASAN}

\section{Kadar Serat Kasar}

Perlakuan kombinasi metode dan suhu blanching memberikan pengaruh yang berbeda nyata terhadap kadar serat kasar batang pisang dapat dilihat pada Gambar 1.

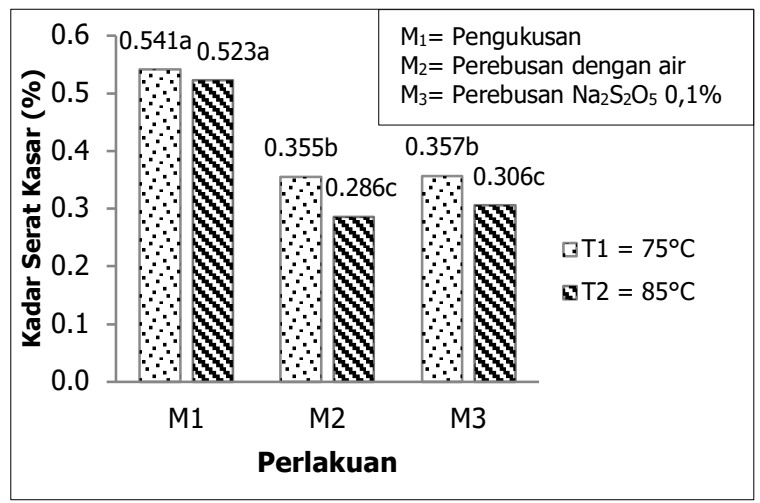

Gambar 1. Grafik Interaksi Metode dan Suhu Blanching terhadap Kadar Serat Kasar Batang Pisang

Berdasarkan Gambar 1 dapat diketahui bahwa kadar serat kasar tertinggi yaitu pada perlakuan $\mathrm{M}_{1} \mathrm{~T}_{1}$ (pengukusan, $75^{\circ} \mathrm{C}$ ) dan kadar serat kasar terendah yaitu pada perlakuan $\mathrm{M}_{2} \mathrm{~T}_{2}$ (perebusan, $85^{\circ} \mathrm{C}$ ). Perlakuan pengukusan menghasilkan kadar serat kasar yang lebih tinggi daripada perlakuan perebusan dengan air maupun perebusan dengan larutan $\mathrm{Na}_{2} \mathrm{~S}_{2} \mathrm{O}_{5}$ 0,1\%. Hal ini disebabkan karena pengukusan 
Versi Online:

http://www.profood.unram.ac.id/index.php/profood e-ISSN: 2443-3446

dilakukan dengan menggunakan media uap panas, sedangkan perebusan menggunakan media air panas. Menurut Muchtadi (2001), komponen seperti pektin dan hemiselulosa dari bahan dapat larut dalam air hangat atau panas. Hal tersebut menyebabkan kadar serat kasar pada metode perebusan lebih rendah daripada metode pengukusan. Perlakuan blanching dengan larutan natrium metabisulfit juga menghasilkan kadar serat kasar yang lebih rendah. Hal ini diduga karena perebusan dengan larutan natrium metabisulfit mengakibatkan sel-sel jaringan pada bahan menjadi lebih mudah terdegradasi (Kumoro dan Hidayat, 2018). Dimana dinding sel tanaman tersebut mengandung antara lain selulosa, hemiselulosa, pektin serta lignin yang termasuk ke dalam komponen serat (Tensiska, 2008).

Berdasarkan penelitian Andini (2017), diperoleh kadar serat kasar batang pisang yaitu sebesar $17,96 \%$. Tingginya perbedaan perolehan kadar serat kasar tersebut dengan hasil yang diperoleh pada penelitian ini yaitu antara 0,286-0,541\% dapat disebabkan oleh beberapa faktor misalnya jenis dan umur dari batang pisang yang digunakan. Penelitian Andini (2017), menggunakan batang pisang batu berumur \pm 11 bulan, sedangkan dalam penelitian ini menggunakan batang pisang kepok berumur \pm 3 bulan. Hal ini didukung oleh penelitian Savitri dkk. (2013), yang menyatakan umur tanaman yang semakin tua mempunyai kandungan dinding sel yang semakin tinggi. Oleh karena itu, semakin tua tanaman maka kandungan seratnya akan semakin meningkat. Selain faktor-faktor tersebut, perlakuan blanching juga menyebabkan kadar serat kasar yang dihasilkan menjadi menurun. Hal ini dikarenakan penggunaan suhu yang lebih tinggi akan menyebabkan kerusakan pada dinding sel bahan.

Penggunaan suhu blanching yaitu $75^{\circ} \mathrm{C}$ dan $85^{\circ} \mathrm{C}$ memberikan pengaruh yang berbeda nyata terhadap kadar serat kasar yang dihasilkan. Berdasarkan Gambar 1 dapat diketahui bahwa suhu yang lebih tinggi
Pro Food (Jurnal Ilmu dan Teknologi Pangan)

Vol 6 No. 1 Mei 2020

ISSN: 2443-1095

$\left(85^{\circ} \mathrm{C}\right)$ akan menghasilkan kadar serat kasar yang lebih rendah pada penggunaan metode blanching yang sama. Semakin tinggi temperatur yang digunakan maka akan menyebabkan semakin rendah kadar serat kasar yang didapatkan. Hal tersebut disebabkan karena adanya degradasi dari pektin atau komponen serat lainnya seperti selulosa dan hemiselulosa selama proses pemanasan (Suprapto, 2004).

Berdasarkan hasil pengamatan dan analisis dapat diketahui bahwa interaksi antara metode dan suhu blanching memberikan pengaruh yang berbeda nyata terhadap kadar serat kasar ares yang dapat dilihat pada Gambar 2. Kadar serat kasar tertinggi yaitu pada perlakuan $M_{1} T_{1}$ (pengukusan, $75^{\circ} \mathrm{C}$ ) dan terendah pada perlakuan $\mathrm{M}_{2} \mathrm{~T}_{2}$ (perebusan, $85^{\circ} \mathrm{C}$ ).

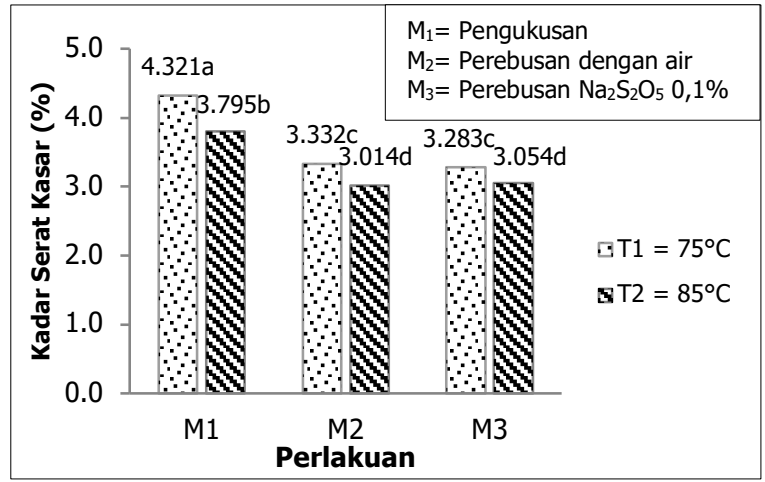

Gambar 2. Grafik Interaksi Metode dan Suhu Blanching terhadap Kadar Serat Kasar Ares

Kadar serat kasar yang diperoleh dari ares mengalami peningkatan dari kadar serat kasar batang pisang sebelum dilakukan pemasakan. Hal tersebut dapat disebabkan karena adanya penambahan bumbu-bumbu selama pemasakan yang mempengaruhi kadar serat kasar dari ares. Adapun bumbubumbu yang digunakan dalam pembuatan ares antara lain bawang merah, bawang putih, jahe, kunyit, lengkuas, kemiri, cabai merah dan cabai rawit. Hal tersebut sesuai dengan penelitian Komalasari dkk. (2016), tentang olahan Lawar dari bonggol pisang, dimana kadar serat kasar bonggol pisang kepok mengalami peningkatan dari 3,60\% menjadi 9,62\% setelah diolah menjadi Lawar. Lawar merupakan olahan khas Bali 
Versi Online:

http://www.profood.unram.ac.id/index.php/profood e-ISSN: 2443-3446

yang dibuat dari bahan-bahan yang hampir sama dengan Ares, hanya saja Lawar tidak menggunakan santan namun menggunakan kelapa parut.

\section{Kadar Serat Pangan Total}

Serat pangan (dietary fiber) adalah komponen bahan makanan nabati yang tahan terhadap proses hidrolisis oleh enzimenzim pada sistem pencernaan manusia. Serat pangan terbagi menjadi dua kelompok yaitu serat pangan tidak larut (insoluble dietary fiber) dan serat pangan larut (soluble dietary fiber) (Tensiska, 2008). Oleh karena itu perhitungan serat pangan total merupakan penjumlahan dari serat pangan tidak larut dan serat pangan larut. Berdasarkan hasil pengamatan dan analisis dapat diketahui bahwa interaksi antara metode dan suhu blanching memberikan pengaruh yang berbeda nyata terhadap kadar serat pangan total dari batang pisang.

Setelah dilakukan penjumlahan kadar serat pangan tidak larut dan kadar serat pangan larut diperoleh kadar serat pangan total batang pisang yang dapat dilihat pada Gambar 3. Berdasarkan Gambar 3 diketahui bahwa kadar serat pangan total tertinggi diperoleh oleh perlakuan $M_{1} T_{1}$ (pengukusan, $75^{\circ} \mathrm{C}$ ) dan terendah pada perlakuan $\mathrm{M}_{3} \mathrm{~T}_{2}$ (perebusan dengan larutan $\left.\mathrm{Na}_{2} \mathrm{~S}_{2} \mathrm{O}_{5} 0,1 \%, 85^{\circ} \mathrm{C}\right)$.

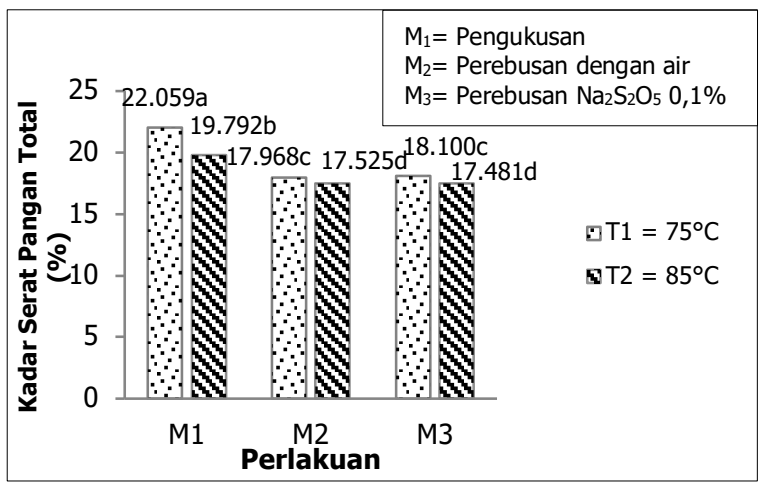

Gambar 3. Grafik Interaksi Metode dan Suhu Blanching terhadap Kadar Serat Pangan Total Batang Pisang

Setelah dilakukan penjumlahan kadar serat pangan tidak larut dan kadar serat pangan larut diperoleh kadar serat
Pro Food (Jurnal Ilmu dan Teknologi Pangan)

Vol 6 No. 1 Mei 2020

ISSN: 2443-1095

pangan total ares yang dapat dilihat pada Gambar 4. Berdasarkan Gambar 4 diketahui bahwa kadar serat pangan total tertinggi diperoleh oleh perlakuan $M_{1} T_{1}$ (pengukusan, $75^{\circ} \mathrm{C}$ ) dan terendah pada perlakuan $\mathrm{M}_{3} \mathrm{~T}_{2}$ (perebusan dengan larutan $\mathrm{Na}_{2} \mathrm{~S}_{2} \mathrm{O}_{5} \mathrm{0,1} \%$, $85^{\circ} \mathrm{C}$ ). Terjadi peningkatan kadar serat pangan total setelah dilakukan pengolahan batang pisang menjadi ares. Hal ini disebabkan karena adanya penambahan bumbu dan rempah-rempah selama proses pemasakan.

Berdasarkan hasil pengamatan, dapat diketahui bahwa kadar serat pangan total memiliki nilai yang lebih tinggi dibandingkan dengan kadar serat kasar dari batang pisang maupun dari ares. Dimana kadar serat pangan batang pisang dan ares secara berurutan yaitu 17,481 - 22,060\% dan 40,448 - 46,058\% sedangkan kadar serat kasar batang pisang dan ares secara berurutan yaitu 0,286 - 0,541\% dan 3,014 $4,321 \%$.

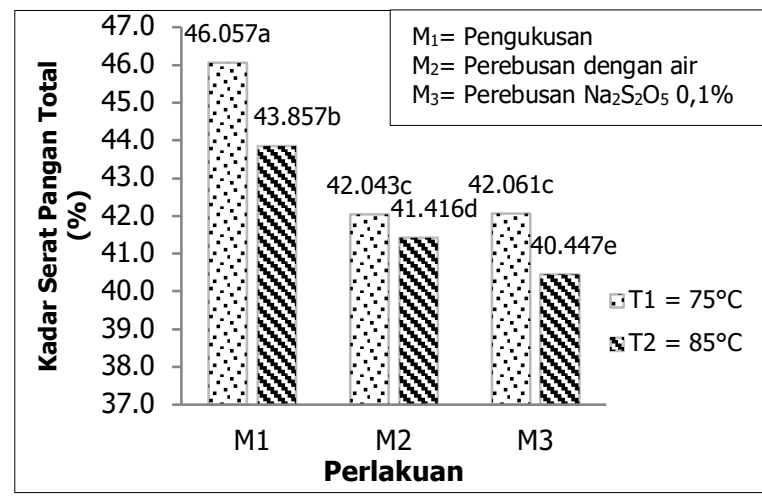

Gambar 4. Grafik Interaksi Metode dan Suhu Blanching terhadap Kadar Serat Pangan Total Ares

Menurut Sudargo dkk. (2014), kadar serat kasar memiliki nilai yang lebih rendah dibandingkan dengan kadar serat pangan, karena asam sulfat dan natrium hidroksida mempunyai kemampuan yang lebih besar untuk menghidrolisis komponen-komponen bahan pangan dibandingkan dengan enzim enzim pencernaan.

Berdasarkan hasil pengamatan dapat diketahui bahwa kadar serat pangan larut memiliki nilai yang lebih rendah daripada serat pangan tidak larut. Menurut Winarno 
Versi Online:

http://www.profood.unram.ac.id/index.php/profood e-ISSN: 2443-3446

(2002), serat pangan larut (soluble dietary fiber) menempati tidak lebih dari sepertiga bagian dari serat pangan total. Hasil analisis kadar serat pangan yang telah dilakukan menunjukkan bahwa fraksi tidak larut lebih mendominasi kandungan total serat pangan. Aziz et al. (2011) dalam Andini (2017), menyatakan bahwa tepung batang pisang memiliki kandungan serat tidak larut berupa selulosa, hemiselulosa dan lignin.

\section{Kadar Serat Pangan Tidak Larut}

Serat pangan terdiri dari serat pangan tidak larut dan serat pangan larut. Serat pangan tidak larut adalah bagian dari serat pangan yang tidak larut di dalam air, yang terdiri dari selulosa, hemiselulosa dan lignin (Tensiska, 2008).

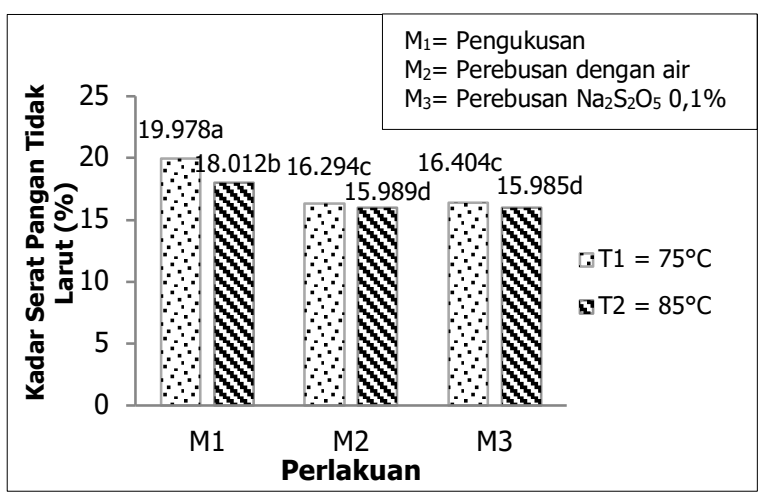

Gambar 5. Grafik Interaksi Metode dan Suhu Blanching terhadap Kadar Serat Pangan Tidak Larut Batang Pisang

Berdasarkan hasil pengamatan dan analisis dapat diketahui bahwa interaksi antara metode dan suhu blanching memberikan pengaruh yang berbeda nyata terhadap kadar serat pangan tidak larut batang pisang yang dapat dilihat pada Gambar 5. Kadar serat pangan tidak larut tertinggi yaitu pada perlakuan $M_{1} T_{1}$ (pengukusan, $75^{\circ} \mathrm{C}$ ) dan terendah pada perlakuan $\mathrm{M}_{3} \mathrm{~T}_{2}$ (perebusan dengan larutan $\mathrm{Na}_{2} \mathrm{~S}_{2} \mathrm{O}_{5} 0,1 \%, 85^{\circ} \mathrm{C}$ ).

Perlakuan pengukusan menghasilkan kadar serat pangan tidak larut tertinggi dibandingkan dengan perlakuan lainnya. Hal tersebut dikarenakan salah satu komponen dari serat pangan tidak larut yaitu hemiselulosa sebenarnya masih dapat ikut
Pro Food (Jurnal Ilmu dan Teknologi Pangan)

Vol 6 No. 1 Mei 2020

ISSN: 2443-1095

larut di dalam air panas. Menurut Izydorczyk, Cui dan Wang (2005) dalam Tensiska (2008), struktur hemiselulosa memiliki rantai cabang yang tidak seragam. Hal inilah yang menyebabkan senyawa tersebut secara parsial dapat larut dalam air. Hal tersebut menyebabkan kadar serat pangan tidak larut pada perlakuan perebusan dengan air dan perebusan dengan larutan $\mathrm{Na}_{2} \mathrm{~S}_{2} \mathrm{O}_{5} \quad 0,1 \%$ lebih rendah daripada perlakuan pengukusan.

Penggunaan larutan $\mathrm{Na}_{2} \mathrm{~S}_{2} \mathrm{O}_{5}$ selama proses perebusan juga dapat mempercepat kerusakan dinding sel bahan. Perendaman dengan menggunakan larutan $\mathrm{Na}_{2} \mathrm{~S}_{2} \mathrm{O}_{5}$ dapat menyebabkan sel-sel jaringan pada bahan menjadi berlubang (Prabasini dkk., 2013). Menurut Suprapto (2004), proses pemanasan pada saat blanching akan menyebabkan struktur gel pektin dan hemiselulosa rusak dan ikut larut di dalam air.

Penggunaan suhu blanching yaitu $75^{\circ} \mathrm{C}$ dan $85^{\circ} \mathrm{C}$ memberikan pengaruh yang berbeda nyata terhadap kadar serat pangan tidak larut yang dihasilkan. Berdasarkan Gambar 5 dapat diketahui bahwa suhu yang lebih tinggi $\left(85^{\circ} \mathrm{C}\right)$ akan menghasilkan kadar serat pangan tidak larut yang lebih rendah $\left(75^{\circ} \mathrm{C}\right)$ pada penggunaan metode blanching yang sama. Hal tersebut sesuai dengan penelitian Widagdo (2007) yang menyebutkan bahwa semakin meningkatnya suhu pemanasan menyebabkan kadar serat pangan semakin menurun.

Berdasarkan hasil pengamatan dan analisis dapat diketahui bahwa interaksi antara metode dan suhu blanching memberikan pengaruh yang berbeda nyata terhadap kadar serat pangan tidak larut ares yang dapat dilihat pada Gambar 6. Kadar serat pangan tidak larut tertinggi yaitu pada perlakuan $\mathrm{M}_{1} \mathrm{~T}_{1}$ (pengukusan, $75^{\circ} \mathrm{C}$ ) dan terendah pada perlakuan $\mathrm{M}_{3} \mathrm{~T}_{2}$ (perebusan dengan larutan $\mathrm{Na}_{2} \mathrm{~S}_{2} \mathrm{O}_{5} 0,1 \%, 85^{\circ} \mathrm{C}$ ).

Kadar serat pangan tidak larut yang diperoleh dari ares mengalami peningkatan dari kadar serat kasar batang pisang sebelum dilakukan pemasakan. Hal tersebut dapat disebabkan karena adanya 
Versi Online:

http://www.profood.unram.ac.id/index.php/profood e-ISSN: 2443-3446

penambahan bumbu-bumbu selama pemasakan yang mempengaruhi kadar serat kasar dari ares.

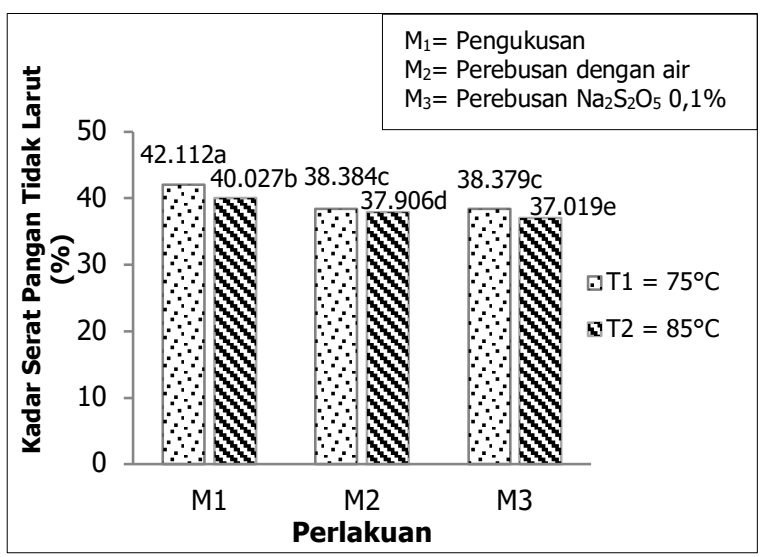

Gambar 6. Grafik Interaksi Metode dan Suhu Blanching terhadap Kadar Serat Pangan Tidak Larut Ares

\section{Kadar Serat Pangan Larut}

Berdasarkan hasil pengamatan dan analisis dapat diketahui bahwa interaksi antara metode dan suhu blanching memberikan pengaruh yang berbeda nyata terhadap kadar serat pangan larut batang pisang yang dapat dilihat pada Gambar 7. Kadar serat pangan larut tertinggi yaitu pada perlakuan $\mathrm{M}_{1} \mathrm{~T}_{1}$ (pengukusan, $75^{\circ} \mathrm{C}$ ) dan terendah pada perlakuan $\mathrm{M}_{3} \mathrm{~T}_{2}$ (perebusan dengan larutan $\mathrm{Na}_{2} \mathrm{~S}_{2} \mathrm{O}_{5} 0,1 \%$, $\left.85^{\circ} \mathrm{C}\right)$.

Serat pangan larut adalah bagian dari serat pangan yang dapat larut di dalam air misalnya gum, pektin dan musilase (Tensiska, 2008). Hal ini menyebabkan blanching dengan cara perebusan air dan perebusan dengan larutan $\mathrm{Na}_{2} \mathrm{~S}_{2} \mathrm{O}_{5}$ menghasilkan kadar serat pangan larut yang lebih rendah dibandingkan dengan blanching dengan cara pengukusan.

Metode perebusan menyebabkan komponen serat akan ikut larut di dalam air selama proses blanching dilakukan. Menurut Winarno (2002) salah satu komponen dari serat pangan yaitu pektin dapat larut di dalam air. Selama proses pemanasan akan terjadi hidrolisis senyawa protopektin yang tidak larut menjadi pektinat (pektin) yang dapat larut di dalam air.

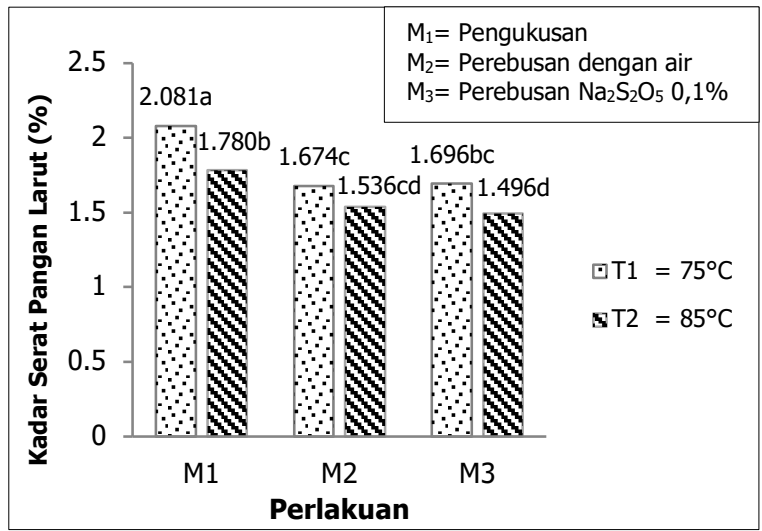

Gambar 7. Grafik Interaksi Metode dan Suhu Blanching terhadap Kadar Serat Pangan Larut Batang Pisang

Perlakuan pemanasan seperti blanching dapat menyebabkan pelepasan komponen sel dan pelarutan dari komponen serat pangan seperti pektin, beta glutans, arabinoxylans dan oligosakarida. Tingkat kelarutan dari komponen dinding sel dipengaruhi oleh sifat kimia dari polisakarida dan ikatannya dengan makromolekul pada dinding sel, serta parameter pemrosesan seperti suhu dan lamanya pemrosesan (Saarela, 2011).

Penggunaan suhu blanching yaitu $75^{\circ} \mathrm{C}$ dan $85^{\circ} \mathrm{C}$ memberikan pengaruh yang berbeda nyata terhadap kadar serat pangan larut yang dihasilkan. Berdasarkan Gambar 7 dapat diketahui bahwa suhu yang lebih tinggi $\left(85^{\circ} \mathrm{C}\right)$ akan menghasilkan kadar serat pangan larut yang lebih rendah $\left(75^{\circ} \mathrm{C}\right)$ pada penggunaan metode blanching yang sama. Menurut Fuestel dan Kueneman (1975) dalam Masuku (2014), meningkatnya waktu dan suhu blanching akan menyebabkan kadar serat pada suatu bahan menurun. Penurunan ini dikarenakan selama proses blanching pori-pori dari bahan akan terbuka dan cairan di dalam bahan akan keluar termasuk serat yang sifatnya larut di dalam air, sehingga kandungan serat pada bahan akan berkurang.

Berdasarkan hasil pengamatan dan analisis dapat diketahui bahwa interaksi antara metode dan suhu blanching memberikan pengaruh yang berbeda nyata terhadap kadar serat pangan larut ares yang dapat dilihat pada Gambar 8. Kadar serat 
Versi Online:

http://www.profood.unram.ac.id/index.php/profood e-ISSN: 2443-3446

pangan larut tertinggi yaitu pada perlakuan $\mathrm{M}_{1} \mathrm{~T}_{1}$ (pengukusan, $75^{\circ} \mathrm{C}$ ) dan terendah pada perlakuan $\mathrm{M}_{3} \mathrm{~T}_{2}$ (perebusan dengan larutan $\mathrm{Na}_{2} \mathrm{~S}_{2} \mathrm{O}_{5} \quad 0,1 \%, 85^{\circ} \mathrm{C}$ ). Terjadi peningkatan kadar serat pangan larut setelah dilakukan pengolahan batang pisang menjadi ares. Hal ini disebabkan karena adanya penambahan bumbu dan rempah-rempah selama proses pemasakan.



Gambar 8. Grafik Interaksi Metode dan Suhu Blanching terhadap Kadar Serat Pangan Larut Ares

\section{Organoleptik Warna}

Hubungan interaksi metode dan suhu blanching terhadap parameter warna batang pisang untuk uji hedonik maupun uji scoring dapat dilihat pada Gambar 9.

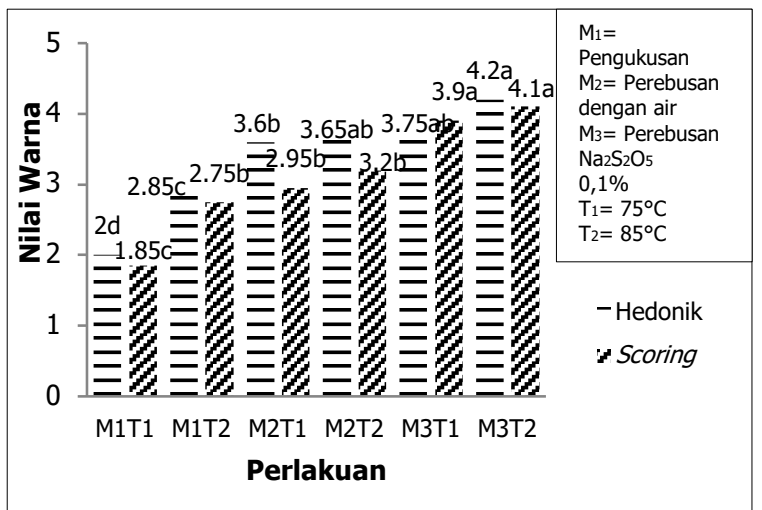

Gambar 9. Grafik Interaksi Metode dan Suhu Blanching terhadap Mutu Organoleptik Warna Batang Pisang

Berdasarkan Gambar 9 dapat dilihat purata pengujian hedonik dan skoring untuk perlakuan $M_{1} T_{1}$ hingga $M_{3} T_{2}$ menunjukkan hasil pengaruh yang berbeda nyata pada
Pro Food (Jurnal Ilmu dan Teknologi Pangan)

Vol 6 No. 1 Mei 2020

ISSN: 2443-1095

interaksi metode dan suhu blanching terhadap mutu organoleptik warna batang pisang. Pada perlakuan $\mathrm{M}_{3} \mathrm{~T}_{2}$ (perebusan dengan larutan $\mathrm{Na}_{2} \mathrm{~S}_{2} \mathrm{O}_{5} \quad 0,1 \%, 8^{\circ} \mathrm{C}$ ) dihasilkan nilai kesukaan warna untuk uji hedonik tertinggi dengan nilai purata 4,2 dan nilai kesukaan terendah yaitu perlakuan $\mathrm{M}_{1} \mathrm{~T}_{1}$ (pengukusan, $75^{\circ} \mathrm{C}$ ) dengan nilai purata 2. Kemudian untuk uji scoring perlakuan dengan nilai tertinggi yaitu pada perlakuan $\mathrm{M}_{3} \mathrm{~T}_{2}$ (perebusan dengan larutan $\mathrm{Na}_{2} \mathrm{~S}_{2} \mathrm{O}_{5} \quad 0,1 \%, 85^{\circ} \mathrm{C}$ ) dengan nilai purata 4,1 dan perlakuan dengan nilai terendah yaitu perlakuan $\mathrm{M}_{1} \mathrm{~T}_{1}$ (pengukusan, $75^{\circ} \mathrm{C}$ ) dengan nilai purata 1,85 . Berdasarkan hal tersebut dapat disimpulkan bahwa nilai purata hedonik dan skoring pada interaksi metode dan suhu blanching terhadap mutu organoleptik warna batang pisang yang didapatkan tersebut masih berada pada skor 1 yang berarti sangat tidak suka dan berwarna cokelat hingga pada skor 4 yang berarti suka dan berwarna putih.

Perlakuan perebusan dengan larutan $\mathrm{Na}_{2} \mathrm{~S}_{2} \mathrm{O}_{5} \quad 0,1 \% \quad$ terbukti mampu mempertahankan warna dari batang pisang dibandingkan dengan perlakuan lainnya. Tan et al. (2015) dalam Wardhani dkk., (2016) menerangkan pencegahan pencokelatan dapat dilakukan karena oksigen yang membantu reaksi pencokelatan akan diikat oleh radikal SO', sehingga reaksi pencokelatan dapat diturunkan kecepatannya.

Perlakuan pengukusan pada suhu $75^{\circ} \mathrm{C}$ menghasilkan batang pisang dengan warna putih kecokelatan. Hal ini disebabkan proses pengukusan menggunakan media uap panas. Media pemanasan dapat mempengaruhi perubahan warna yang terjadi pada bahan. Salah satu senyawa polifenol yang dapat menyebabkan pencokelatan pada batang pisang adalah senyawa tanin. Menurut Komalasari, dkk. (2016), kadar tanin pada batang pisang kepok yaitu 0,36\%. Menurut Andarwulan dan Faradilla (2012), semua jenis tanin dapat larut dalam air, kelarutannya besar dan akan bertambah besar apabila dilarutkan di dalam 
Versi Online:

http://www.profood.unram.ac.id/index.php/profood e-ISSN: 2443-3446

air panas. Tanin akan berubah menjadi warna yang lebih gelap apabila terkena cahaya atau dibiarkan di udara terbuka. Hal tersebut menyebabkan kerusakan tanin akan lebih besar pada perlakuan perebusan daripada pengukusan, sehingga akan diperoleh warna batang pisang yang lebih putih.

Hubungan interaksi metode dan suhu blanching terhadap parameter warna ares dapat dilihat pada gambar 10 .

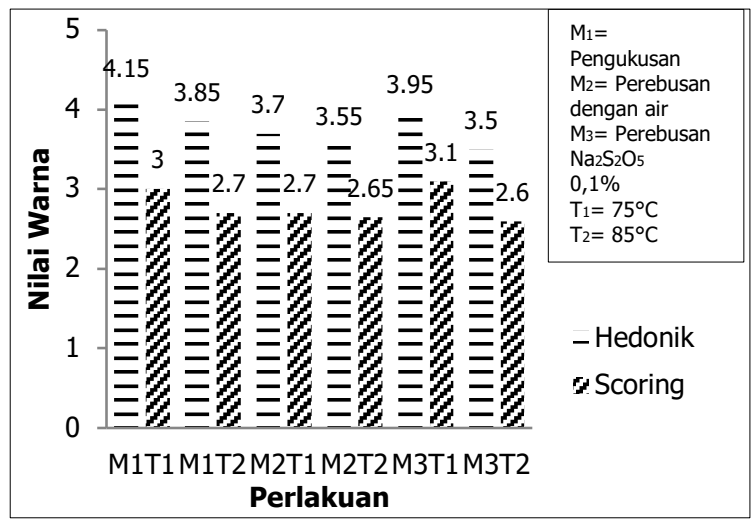

Gambar 10. Grafik Interaksi Metode dan Suhu Blanching terhadap Mutu Organoleptik Warna Ares

Berdasarkan Gambar 10 dapat dilihat purata pengujian hedonik dan skoring untuk perlakuan $M_{1} T_{1}$ hingga $M_{3} T_{2}$ menunjukkan hasil pengaruh yang tidak berbeda nyata pada interaksi metode dan suhu blanching terhadap mutu organoleptik warna ares. Nilai purata yang terlihat mengalami penurunan pada pengujian hedonik dengan skor 4 ke 3 yang berarti dari suka ke tidak suka sedangkan untuk pengujian skoring mengalami dengan skor 3 ke 2 yang berarti dari berwarna agak kuning ke cokelat. Hal tersebut disebabkan karena seluruh perlakuan diberikan konsentrasi bumbu yang sama selama proses pemasakan. Warna ares dipengaruhi oleh bumbu-bumbu yang ditambahkan selama proses pemasakan.

\section{Organoleptik Tekstur}

Hubungan interaksi metode dan suhu blanching terhadap parameter tekstur batang pisang untuk uji hedonik maupun uji scoring dapat dilihat pada Gambar 11.

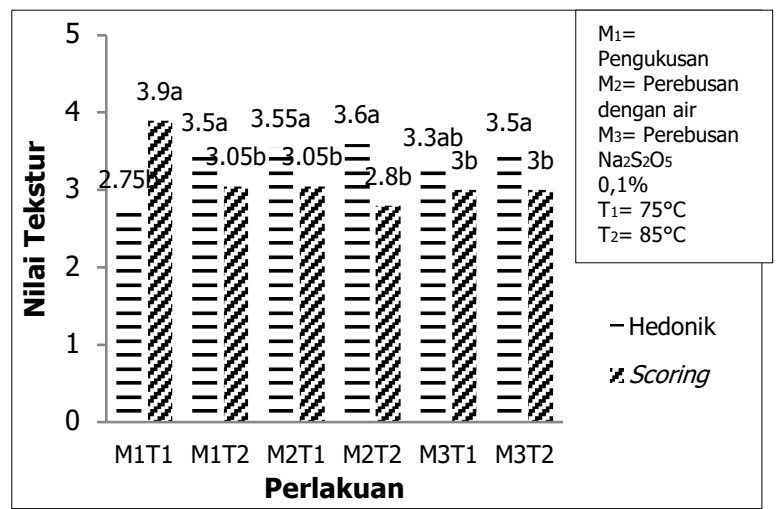

Gambar 11. Grafik Interaksi Metode dan Suhu Blanching terhadap Mutu Organoleptik Tekstur Batang Pisang

Berdasarkan Gambar 11 dapat dilihat purata pengujian hedonik dan skoring untuk perlakuan $M_{1} T_{1}$ hingga $M_{3} T_{2}$ menunjukkan hasil pengaruh yang berbeda nyata pada interaksi metode dan suhu blanching terhadap mutu organoleptik tekstur batang pisang. Pada perlakuan $\mathrm{M}_{2} \mathrm{~T}_{2}$ (perebusan dengan air, $85^{\circ} \mathrm{C}$ ) dihasilkan nilai kesukaan tekstur untuk uji hedonik tertinggi dengan nilai purata 3,55 dan nilai kesukaan terendah dengan nilai purata 2,75 untuk perlakuan $M_{1} T_{1}$ (Pengukusan, $75^{\circ} \mathrm{C}$ ). Kemudian untuk pengujian scoring, nilai tertinggi diperoleh pada perlakuan $M_{1} T_{1}$ (Pengukusan, $75^{\circ} \mathrm{C}$ ) dengan purata 3,9 dan nilai terendah pada uji scoring diperoleh perlakuan $\mathrm{M}_{2} \mathrm{~T}_{2}$ (perebusan dengan air, $85^{\circ} \mathrm{C}$ ) dengan purata 2,8. Berdasarkan hal tersebut dapat disimpulkan bahwa nilai purata hedonik dan skoring pada interaksi metode dan suhu blanching terhadap mutu organoleptik tekstur batang pisang yang didapatkan tersebut masih berada pada skor 2 yang berarti tidak suka dan lunak hingga pada skor 3 yang berarti agak suka dan agak lunak.

Berdasarkan Gambar 11 dapat diketahui bahwa metode blanching dengan perebusan menghasilkan tekstur batang pisang yang lebih lunak daripada pengukusan. Menurut Asgar dan Musaddad (2008), blanching yang terlalu lama di dalam air panas cenderung akan menghasilkan bahan dengan tekstur yang lebih lunak dan dapat menyebabkan kehilangan nutrien. Hal 
Versi Online:

http://www.profood.unram.ac.id/index.php/profood e-ISSN: 2443-3446

tersebut dapat terjadi karena adanya kerusakan lignin dan komponen selulosa pada dinding sel bahan sejalan dengan bertambahnya waktu dan temperatur blanching (Miao et al., 2011 dalam Badwaik dkk., 2015).

Penggunaan suhu blanching yaitu $75^{\circ} \mathrm{C}$ dan $85^{\circ} \mathrm{C}$ memberikan pengaruh yang berbeda nyata terhadap tekstur dari batang pisang. Penggunaan suhu yang lebih tinggi akan menghasilkan tekstur bahan yang lebih lunak. Hal tersebut sesuai dengan penelitian Badwaik dkk. (2015), dimana tekstur dari batang bambu mengalami penurunan dengan adanya peningkatan waktu dan suhu blanching yang diberikan. Pelunakan tekstur tersebut terjadi selama lima menit pertama dari proses blanching dan terus meningkat dengan semakin tingginya suhu yang digunakan.

Hubungan interaksi metode dan suhu blanching terhadap parameter tekstur ares untuk uji hedonik maupun uji scoring dapat dilihat pada Gambar 12.

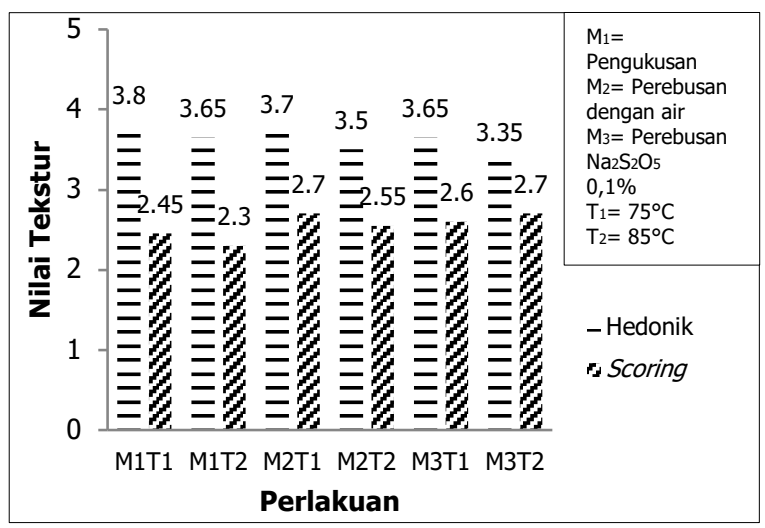

Gambar 12. Grafik Interaksi Metode dan Suhu Blanching terhadap Mutu Organoleptik Tekstur Ares

Berdasarkan Gambar 12 dapat dilihat purata pengujian hedonik dan skoring untuk perlakuan $M_{1} T_{1}$ hingga $M_{3} T_{2}$ menunjukkan hasil pengaruh yang tidak berbeda nyata pada interaksi metode dan suhu blanching terhadap mutu organoleptik tekstur ares. Nilai purata secara keseluruhan berada pada rentang skor masih 3 untuk hedonik yang berarti agak suka dan skor masih 2 untuk skoring yang berarti lunak. Hal tersebut
Pro Food (Jurnal Ilmu dan Teknologi Pangan)

Vol 6 No. 1 Mei 2020

ISSN: 2443-1095

dapat disebabkan karena lamanya waktu pemasakan untuk seluruh perlakuan adalah sama yaitu selama 30 menit.

\section{Organoleptik Rasa}

Hubungan interaksi metode dan suhu blanching terhadap parameter rasa batang pisang untuk uji hedonik maupun uji scoring dapat dilihat pada Gambar 13.

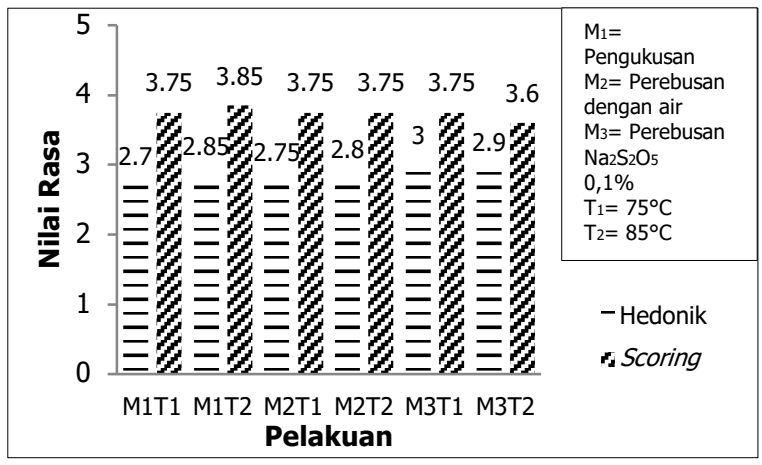

Gambar 13. Grafik Interaksi Metode dan Suhu Blanching terhadap Mutu Organoleptik Rasa Batang Pisang

Berdasarkan Gambar 13 dapat dilihat purata pengujian hedonik dan skoring untuk perlakuan $M_{1} T_{1}$ hingga $M_{3} T_{2}$ menunjukkan hasil pengaruh yang tidak berbeda nyata pada interaksi metode dan suhu blanching terhadap mutu organoleptik tekstur ares. Nilai purata secara keseluruhan berada pada rentang skor masih 2 untuk hedonik yang berarti tidak suka dan skor masih 3 untuk skoring yang berarti agak sepat. Menurut Sompotan (2012), batang pisang kepok biasanya memiliki rasa yang agak manis dan tidak terlalu sepat seperti jenis pisang lainnya. Rasa sepat pada bahan tersebut dapat berasal dari tanin (Suhirman dkk., 2006). Berdasarkan penelitian Komalasari dkk. (2016), kadar tanin pada batang pisang kepok yaitu $0,36 \%$, dimana hasil tersebut lebih rendah daripada kadar tanin pada batang pisang raja, pisang susu dan pisang muli yang secara berturut-turut yaitu $0,45 \%$; $0,40 \%$ dan $0,46 \%$.

Hubungan interaksi metode dan suhu blanching terhadap parameter rasa ares untuk uji hedonik maupun uji scoring dapat dilihat pada Gambar 14. 
Versi Online:

http://www.profood.unram.ac.id/index.php/profood e-ISSN: 2443-3446

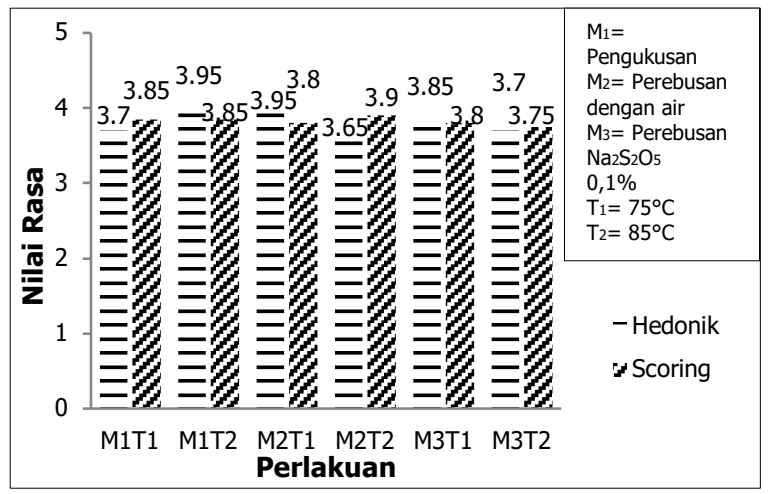

Gambar 14. Grafik Interaksi Metode dan Suhu Blanching terhadap Mutu Organoleptik Rasa Ares

Berdasarkan Gambar 14 dapat dilihat purata pengujian hedonik dan skoring untuk perlakuan $M_{1} T_{1}$ hingga $M_{3} T_{2}$ menunjukkan hasil pengaruh yang tidak berbeda nyata pada interaksi metode dan suhu blanching terhadap mutu organoleptik rasa ares. Nilai purata secara keseluruhan pengujian hedonik dan skoring berada pada rentang skor masih 3 yaitu ares memiliki rasa agak suka dan agak gurih. Timbulnya rasa gurih yang sama dikeseluruhan perlakuan pada ares dikarenakan penambahan bumbu dan rempah-rempah yang jumlahnya sama untuk keseleruhan perlakuan selama proses pemasakan.

\section{KESIMPULAN}

Berdasarkan hasil analisis dan pembahasan yang terbatas pada ruang lingkup penelitian ini, maka dapat ditarik beberapa kesimpulan sebagai berikut:

1. Perlakuan kombinasi metode dan suhu blanching pada batang pisang dan ares memberikan pengaruh yang berbeda nyata terhadap kadar serat kasar, serat pangan tidak larut, serat pangan larut dan serat pangan total.

2. Perlakuan kombinasi metode dan suhu blanching pada batang pisang memberikan pengaruh yang berbeda nyata pada mutu organoleptik warna dan tekstur, serta tidak memberikan pengaruh yang berbeda nyata pada mutu organoleptik rasa. Sedangkan kombinasi metode dan suhu blanching
Pro Food (Jurnal Ilmu dan Teknologi Pangan)

Vol 6 No. 1 Mei 2020

ISSN: 2443-1095

tidak memberikan pengaruh yang berbeda nyata pada mutu organoleptik warna, tekstur dan rasa dari ares yang dihasilkan.

3. Hasil terbaik pada batang pisang berdasarkan mutu nutrisi serat adalah perlakuan pengukusan pada suhu $75^{\circ} \mathrm{C}$ dengan kadar serat kasar 0,541\%, serat pangan total $22,926 \%$, serat pangan tidak larut $19,978 \%$ dan serat pangan larut $2,081 \%$.

4. Hasil terbaik pada ares berdasarkan mutu nutrisi serat adalah perlakuan pengukusan pada suhu $75^{\circ} \mathrm{C}$ dengan kadar serat kasar $4,321 \%$, serat pangan total $46,057 \%$, serat pangan tidak larut $42,112 \%$ dan serat pangan larut $3,945 \%$.

\section{DAFTAR PUSTAKA}

Ahda, Y. dan S. H. Berry. 2008. Pengolahan Limbah Kulit Pisang menjadi Pektin dengan Metode Ekstraksi. http://eprints.undip.ac.id/3671/1/MA KALAH Yusuf Ahda.pdf. (Diakses pada tanggal 05 Mei 2018).

Andarwulan, N. dan F. Faradilla. 2012. Senyawa Fenolik pada Beberapa Sayuran Indigenous dari Indonesia. SEAFAST Center IPB. Bogor.

Andini, P.L. 2017. Pengaruh Pengecilan Ukuran pada Tepung Batang Pisang batu terhadap Potensinya sebagai Serat Pangan. Skripsi. Institut Pertanian Bogor. Bogor.

Anonim. 2006. Serat Makanan dan Kesehatan.

http://tekpan.unimus.ac.id/wpcontent/uploads/2013/07/SERATMAKANAN-DAN-KESEHATAN.pdf. (Diakses pada tanggal 06 Mei 2018).

Anonim. 2017b. BAB I: Pendahuluan. http://digilib.unila.ac.id/13918/13/13 -\%20BAB\%20I.pdf (Diakses pada tanggal 05 Mei 2018).

Arsa. M. 2016. Proses Pencoklatan (Browning Process) pada Bahan Pangan. Universitas Udayana. Denpasar. 
Versi Online:

http://www.profood.unram.ac.id/index.php/profood e-ISSN: 2443-3446

Asgar, A. dan D. Musaddad. 2006b. Optimalisasi Cara, Suhu, dan Lama Blansing sebelum Pengeringan Kubis. J. Hort 16(4): 349.

Asgar, A. dan D. Musaddad. 2008. Pengaruh Media, Suhu, dan Lama Blansing Sebelum Pengeringan terhadap Mutu Lobak Kering. J. Hort 18(1): 87.

Aziz NAA., Ho LH, Azahari B., Bhat R., Cheng LH., Nasir dan M, Ibrahim M. 2011. Chemical and functional properties of the native banana (Musa acuminate $x$ balbisiana colla cv. Awak) pseudostem and pseudo-stem tender core flours. Food Chemistry. 128 (2) : 748-753.

Badan Pusat Statistik. 2015. Statistik Tanaman Buah-buahan dan Sayuran Tahunan Indonesia. Badan Pusat Statistik. Jakarta.

Badan Pusat Statistik Provinsi NTB. 2017. Statistik Produksi Tanaman Holtikultura Provinsi Nusa Tenggara Barat 2017. Badan Pusat Statistik Provinsi Nusa Tenggara Barat. Mataram.

Badwaik, L. S., G. Gautam. dan S. C. Deka. 2015. Influence of Blanching on Antioxidant, Nutritional and Physical Properties of Bamboo Shoot. The Journal of Agricultural Sciences 10(3): 140-150.

Dewati, R. 2008. Limbah Kulit Pisang Kepok sebagai Bahan baku Pembuatan Etanol. UPN Press. Surabaya.

Izydorczyk, M., S. W. Cui dan Q. Wang. 2005. Polysaccharide gums. structures, functional properties and applications. In Food Carbohydrates, Chemistry, Physical Properties and Applications. Taylor \& Francis Group, CRC Press. Boca Raton.

Fuestel, T. C., dan R. W Kueneman. 1975. Frozen French Fries and Other Potato Product. In Potatotes Production Storing, Processing. Second Edition O'Smith (editor) Avi Publishing Co., Inc. Westport, Con.

Komalasari, N., K. Suter dan L. Darmayanti. 2016. Kajian Karakteristik Lawar Bonggol Pisang. Jurnal ITEPA 5(1): 1-10.
Pro Food (Jurnal Ilmu dan Teknologi Pangan)

Vol 6 No. 1 Mei 2020

ISSN: 2443-1095

Kumoro, A. dan J. Hidayat. 2018. Effect of Soaking Time in Sodium Metabisulfite Solution on the Physicochemical and Functional Properties of Durian Seed Flour. MATEC Web of Conferences 156, 01028.

Kusdibyo dan D. Musaddad. 2000. Teknik Perlakuan Blansing pada Pengeringan Sayuran Wortel dan Kubis. Laporan Penelitian T.A 1999/2000. Balitsa Lembang.

Kusnandar, F. 2010. Kimia Pangan: Komponen Makro. Dian Rakyat. Jakarta.

Masuku, A.M. 2014. Efektifitas Konsentrasi Natrium Bisulfit dan Lama Blanching terhadap Parameter Kualitas Tepung Jambu Mete. Jurnal IImiah Agribisnis dan Perikanan 7(2): 1-6.

Miao, M., Wang, Q., Zhang, T. dan Jiang, B. 2011. Effect of High Hydrostatic Pressure (HHP) Treatment on Texture Changes of Water Bamboo Shoots Cultivated in China. Postharvest Biology and Technology, 59(3): 327-329.

Muchtadi, D. 2001. Sayuran Sebagai Sumber Serat Pangan untuk Mencegah Timbulnya Penyakit Degeneratif. Jurnal Teknd XU(1): 1-11.

Prabasini, H., D. Ishartani dan D. Rahadian. 2013. Kajian Sifat Kimia dan Fisik Tepung Labu Kuning (Cucurbita moschata) dengan Perlakuan Blanching dan Perendaman dalam Natrium Metabisulfit $\left(\mathrm{Na}_{2} \mathrm{~S}_{2} \mathrm{O}_{5}\right)$. Jurnal Teknosains Pangan 2(2): 110.

Saarela, M. 2011. Functional Foods; Concept to product, Second edition. Woodhead Publishing Limited. UK.

Savitri, M.V., H. Sudarwati dan Hermanto. 2013. Pengaruh Umur Pemotongan terhadap Produktivitas Gamal (Gliricidia sepium). Jurnal IImu-IImu Peternakan 23(2): 25-35.

Soebyanto, O., B. A. Sekarwati, dan R. Susanto. 2018. Lezatnya Sayur Ares Berbahan Dasar Batang Pisang sebagai Makanan Khas Suku Sasak di Kabupaten Lombok Barat Nusa 
Versi Online:

http://www.profood.unram.ac.id/index.php/profood e-ISSN: 2443-3446

\author{
Tenggara Barat. Jurnal \\ Kepariwisataan 12(1): 1-13.
}

Sompotan, J. 2012. Eits, Jangan Buang Batang Pisang.

https://lifestyle.okezone.com/read/2

012/02/17/488/577948/eits-jangan-

buang-batang-pisang. (Diakses pada

tanggal 31 Desember 2018).

Sudargo, T., Harry, F., Felicia, R. dan N. A. Kusmayanti. 2014. Pola Makan dan Obesitas. Gajah Mada University Press. Yogyakarta.

Suhirman, S., EA. Hadad dan Lince. 2006. Pengaruh Penghilang Tanin dari Jenis Pala terhadap Sari Buah Pala.,Bul. Littro XVII(1): 39-52.

Suprapto. 2004. Pengaruh Lama Blanching terhadap Kualitas Stik Ubijalar (Ipoema Batatas L.) dari Tiga Varietas. Balai Penelitian Tanaman Kacang-kacangan dan Umbi-umbian. Malang.

Tan, T. C., Cheng, L. H., Bhat, R., Rusul, G., dan Easa, A. M.2015. Effectiveness of Ascorbic Acid and Sodium Metabisulfite As Anti-Browning Agent and Antioxidant on Green Coconut Water (Cocos nucifera) Subjected to Elevated Thermal Processing. International Food Research Journal. 22 (2) : 631-637.

Tensiska. 2008. Serat Makanan. Universitas Padjadjaran. Bandung.

Wahyuni, Z. A. 2017. Pengaruh Lama Sterilisasi pada Proses Pengalengan terhadap Mutu dan Masa Simpan Ares. Skripsi. Fakultas Teknologi Pangan dan Agroindustri Universitas Mataram. Mataram.

Wardhani, D. H., A. Yuliana dan A. Dewi. 2016. Natrium Metabisulfit sebagai Anti-Browing Agent pada Pencoklatan Enzimatik Rebung Ori (Bambusa Arundinacea). Jurnal Aplikasi Teknologi Pangan. 5(4): 140-145.

Widagdo, K. 2007. Pengaruh Perlakuan Pemanasan terhadap Kadar Amilosa dan Serat Pangan Beras Merah Organik. Skripsi. Program Studi Teknologi Pangan Unika Soegijapranata. Semarang.
Pro Food (Jurnal IImu dan Teknologi Pangan)

Vol 6 No. 1 Mei 2020

ISSN: 2443-1095

Winarno, F. G. 2002. Kimia Pangan dan Gizi. Gramedia Pustaka Utama. Jakarta.

Yustitia. 2012. Ares, Makanan yang Diracik dari Pelepah Pisang. http://lombok.panduanwisata.id/wisa ta-kuliner/ares-makanan-yangdiracik-dari-pelepah-pisang/ (Diakses pada tanggal 05 Mei 2018). 